\title{
Treatment of Textile Industry Wastewater using Microbial Fuel Cell
}

\author{
C.Marimuthu, S.Vidya, S. Diwakaran
}

\begin{abstract}
Recent research have found out that Bio Electrochemical Systems (BES) are proving to be efficient in both power generation and in waste disposal. The best example for a BES is a microbial fuel cell. The microbial fuel cell (MFC) uses the organic and the inorganic materials in the wastewater to produce electricity by the action of the microbes on them. Thus the MFC's can be used for both bio-electricity generation and wastewater treatment. The power generation and the efficiency of the MFC depends on various factors like the type of bacteria, type of electrode used and organic content in the effluent. Experiments were carried out to treat textile industry wastewater using Microbial Fuel Cell. Graphite was used as anode, stainless steel and aluminium mesh were used as cathode. Influence of cathodes on power production and COD reduction on process has been critically examined. The maximum power density and COD reduction were observed in graphite and stainless steel electrode system
\end{abstract}

Keywords : Electricity, Electrode, Microbes, Microbial fuel cell, textile wastewater treatment.

\section{INTRODUCTION}

The major problem faced by a developing country is clean energy production1 and the disposal of waste. Many new methods have been developed for waste disposal and production of clean energy but most of them are not economically feasible and are still in research. The new methods proposed entail high operational costs or large of lands for the treatment [2].Thus, active research to find out alternate methods to treat wastewater and to find new sources of energy especially renewable sources of energy is a new trend [3]. The new systems called Bio Electrochemical Systems 4 are new method of clean power generation. The microbial fuel cell are one such BES that can be used for the power generation. The MFC works on the anaerobic breakdown of the substrate or organic matter present in the wastewater by the bacteria present in it. Microbial fuel cell (MFC) is a novel device which can directly convert organic substrate into electricity [5]. Electricity producing microorganism are called as Electricigens.

Revised Manuscript Received on December 05, 2019.

* Correspondence Author

C.Marimuthu*, Department of Chemical Engineering, Sethu Institute of Technology, Pulloor, Kariapatti, Virudhunagar, India. Email: marimuthupetro@gmail.com

S.Vidya, Department of Computer Science and Engineering, Kalasalingam Institute of Technology, Krishnankovil, Srivilliputhur, India. Email:

vidya.1kshm@gmail.com

S.Diwakaran, Department of Electronics and CommunicationEngineering,Kalasalingam Academy of Research and Education, Krishnankovil, Srivilliputhur, India. Email: s.diwakaran.ece@gmail.com
Electricigens make it possible to convert renewable biomass and organic wastes directly into electricity without combusting the fuel, which wastes substantial amounts of energy as heat [6].

Most basic fuel cell consist of two chamber, an anaerobic and anode and aerated cathode separated by membrane such as Naffion or salt bridge. Membrane or salt bridge allows hydrogen ions generated in the anode chamber to the cathode chamber [7]. Most biological fuel cells use mediator molecule to speed up produced electrons to electrode surface. Recently, mediator-less microbial fuel cells have been developed. These kinds of microbial fuel can directly transfer electrons to the electrodes [8-10].

Water based organic matters that can be used in an MFC can be simple carbohydrates, acetate and butyrate, and complex organic compounds, domestic wastewater, and manure sludge [11]. The wastewater is usually taken in the anode chamber and a cathode chamber is filled with water. The electrodes are inserted in the respective chambers. The external circuit is closed by connecting the electrodes. In anaerobic conditions the bacteria breakdowns the organic matter producing electrons and protons [12]. The electrons are transferred to the anode which passes it to the external circuit thus current is produced in the opposite direction of the electrons flow. The protons are exchanged through the proton exchange membrane, they reach the cathode compartment and combine with oxygen to form water. Microbial fuel cells use biocatalysts for the conversion of chemical energy to electrical energy [13-15].

The Schematic diagram of a MFC is represented in figure 1.

The basic reaction taking place I the anode and cathode chamber of an MFC are given below [16]

Acetate is used as substrate fuel for wastewater

Anode : $\mathrm{CH}_{3} \mathrm{COOH}+2 \mathrm{H}_{2} \mathrm{O} \rightarrow 2 \mathrm{CO}_{2}+8 \mathrm{H}^{+}+8 \mathrm{e}^{-}$

Cathode: $2 \mathrm{O}_{2}+8 \mathrm{H}^{+}+8 \mathrm{e}^{-} \rightarrow 4 \mathrm{H}_{2} \mathrm{O}$

Overall: $\mathrm{CH}_{3} \mathrm{COOH}+2 \mathrm{O}_{2} \rightarrow 2 \mathrm{CO}_{2}+2 \mathrm{H}_{2} \mathrm{O}+$ electricity

The various factors that affect the power production in MFC are [17]

$>$ Electrode used
$>$ Shape of the electrode
$>$ Size of the cathode
Types of microbes present in the
wastewater
$>$ Proton exchange membrane

Due to the breakdown of the organic matters in the waste water the COD level of the effluent decreases 


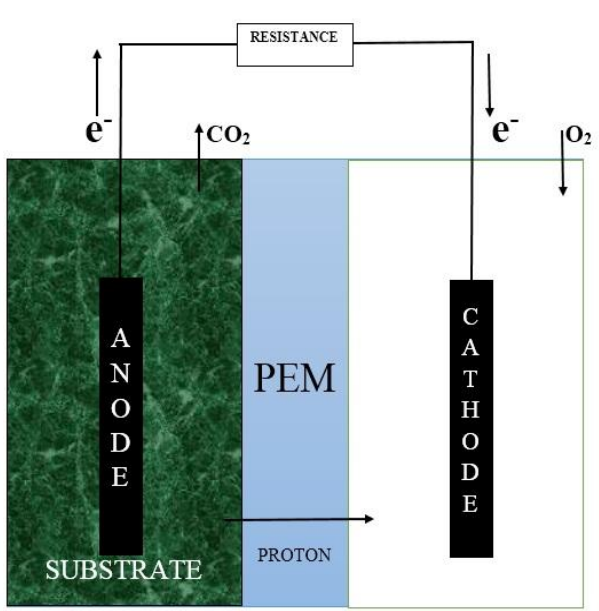

Fig 1. Schematic representation of an MFC

\section{MATERIAL AND METHODS}

\section{A. Textile Industry Wastewater}

Textile industry waste water was collected from a common effluent treatment plant in Tirupur district of Tamilnadu. The effluent was stored in refrigerator at $40^{\circ} \mathrm{C}$ to avoid the contamination. The test was conducted without any modifications to the wastewater like $\mathrm{pH}$ adjustments or addition of nutrients [18]. The figure 2 shows the textile effluent collected from industries.

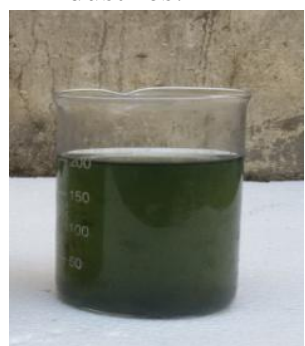

Fig 2. Textile Industry Waste water

\section{B. MFC configuration and operation}

Experiment was carried out using fabricated two simple two chambered microbial fuel cell with the help of four $900 \mathrm{ml}$ airtight containers. Graphite anodes were used since it's the most abundantly used one and its cost is low approximately Rs. 80 per kg. [19]. Stainless steel mesh was used as cathode for MFC configuration -1 and aluminum mesh as cathode for MFC configuration- 2 . The properties of the electrode are given below in the table 1 .

Table- I: Properties of Electrode

\begin{tabular}{|l|l|l|l|}
\hline Electrode & $\begin{array}{l}\text { Graphite } \\
\text { Electrodes }\end{array}$ & $\begin{array}{l}\text { Stainless } \\
\text { Steel } \\
\text { Electrode }\end{array}$ & $\begin{array}{l}\text { Aluminium } \\
\text { Electrode }\end{array}$ \\
\hline Shape & Cylindrical & $\begin{array}{l}\text { Rectangular } \\
\text { Mesh }\end{array}$ & $\begin{array}{l}\text { Rectangular } \\
\text { Mesh }\end{array}$ \\
\hline $\begin{array}{l}\text { Effective } \\
\text { area }\end{array}$ & $12.26 \mathrm{~cm}^{2}$ & $60.37 \mathrm{~cm}^{2}$ & $60.52 \mathrm{~cm}^{2}$ \\
\hline $\begin{array}{l}\text { Cathode/An } \\
\text { ode }\end{array}$ & Anode & Cathode & Cathode \\
\hline \begin{tabular}{l} 
Dimensions \\
\hline
\end{tabular} & $\begin{array}{l}\mathrm{L}=6 \mathrm{~cm}, \mathrm{D}= \\
1.3 \mathrm{~cm}\end{array}$ & $\begin{array}{l}\mathrm{L}=30 \mathrm{~cm}, \mathrm{~B} \\
=6.5 \mathrm{~cm}\end{array}$ & $\begin{array}{l}\mathrm{L}=30 \mathrm{~cm}, \\
\mathrm{~B}=7 \mathrm{~cm}\end{array}$ \\
\hline
\end{tabular}

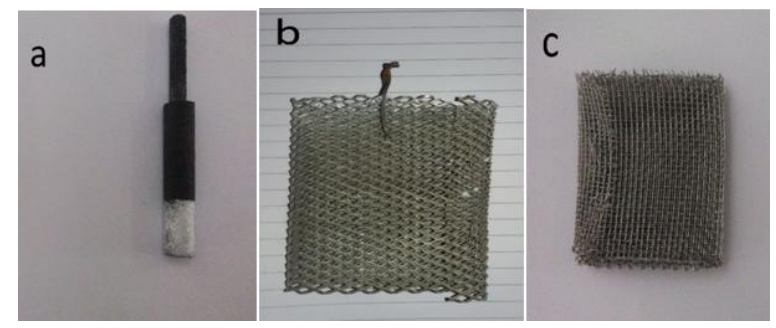

Fig. 3. (a) Graphite Electrode, (b) Aluminum Electrode, (c) Stainless Steel Electrode

An Agar salt bridge was used as a Proton exchange membrane. $800 \mathrm{ml}$ of the effluent was taken in the anode chamber and the cathode chamber was filled with $700 \mathrm{ml}$ ordinary tap water. The respective electrode was inserted in the respective chambers. The anode chamber was sealed air tight to maintain anaerobic condition and the cathode chamber was provided with a hole to supply air. The electrodes were externally connected to the multimeter with copper wires. No pre-treatment was done to the electrodes.

\section{Analysis}

The COD, pH, TSS, and TDS analysis of the effluent was done before the test. The results are as shown in the following table 2 .

Table- II: Textile Effluent Characteristics

\begin{tabular}{|l|l|l|}
\hline S.no & Property & Effluent characteristics \\
\hline 1 & $\mathrm{pH}$ & 7.2 \\
\hline 2 & COD & $2960 \mathrm{ppm}$ \\
\hline 3 & Colour & Dark Green \\
\hline 4 & TDS & $6000 \mathrm{ppm}$ \\
\hline 5 & TSS & $1200 \mathrm{ppm}$ \\
\hline
\end{tabular}

The MFC was operated and the voltage was measured using the multimeter. The Current was measured across an external resistance of $470 \mathrm{ohm}$ using the following formula [20].

Current $=$ Voltage/External resistance ,

$\mathrm{I}=\mathrm{V} / \mathrm{R}_{\mathrm{ext}}$ (Ampere)

Current Density $=$ Current/Area,

$\mathrm{J}=\mathrm{I} / \mathrm{A}\left(\right.$ Ampere $/ \mathrm{m}^{2}$ )

The power was measured was calculated using the formula Power $=$ Voltage $\mathrm{x}$ Current, $\mathrm{P}=\mathrm{V} \times \mathrm{I}$ (mWatt)

Power density $=$ Current density $x$ Voltage, $\mathrm{PD}=\mathrm{J} \times \mathrm{V}\left(\mathrm{mW} / \mathrm{m}^{2}\right)$

\section{RESULT AND DISCUSSION}

The output of both MFCs were observed for 17 days based on the literature [1]. The corresponding current and power density was calculated using the above mentioned formulas. Graphs of Time vs Voltage, Time vs Power density and Voltage vs Power density were drawn for each MFC configurations

\section{A. MFC configuration-1}

The total power generated for $1 \mathrm{~m}^{2}$ area of the stainless steel electrode was $35626.77 \mathrm{~mW}$. The Actual power generated from the electrode area of $0.001225 \mathrm{~m}^{2}$ is $43.19 \mathrm{~mW}$. 


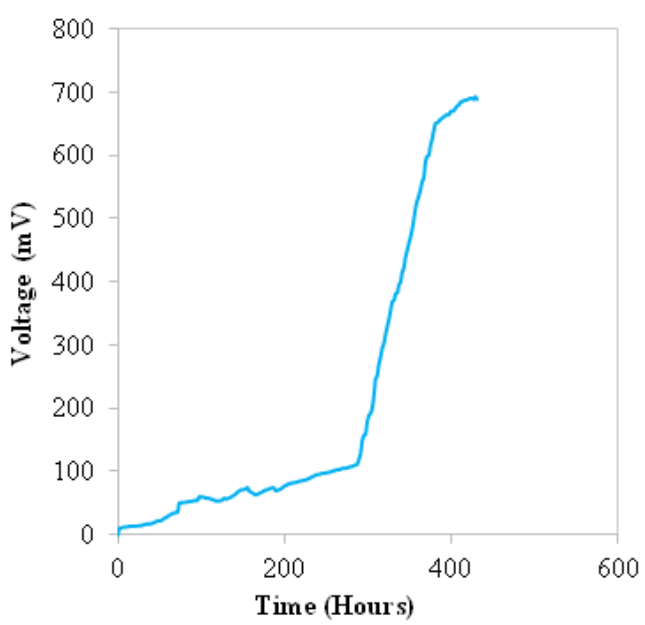

Fig 4. Voltage vs Time graph for Stainless Steel Cathode and Graphite Anode

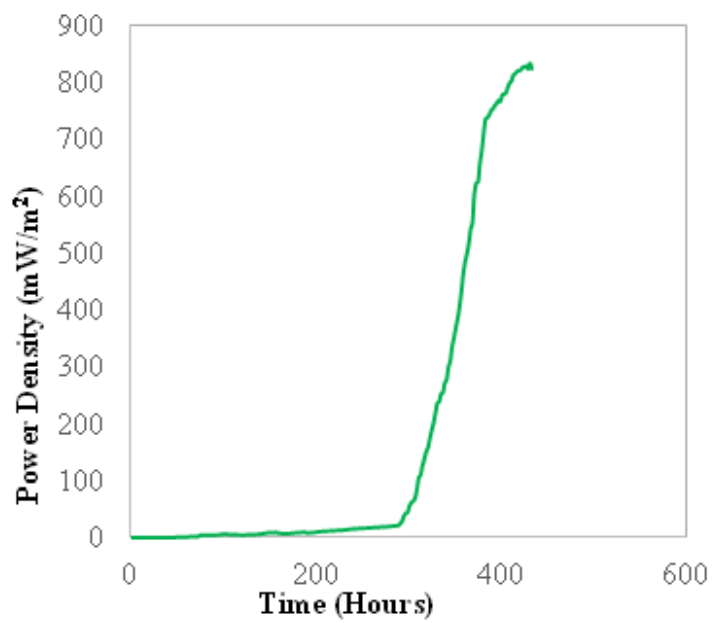

Fig 5. Power density vs Time graph I Stainless Steel Cathode and Graphite Anode

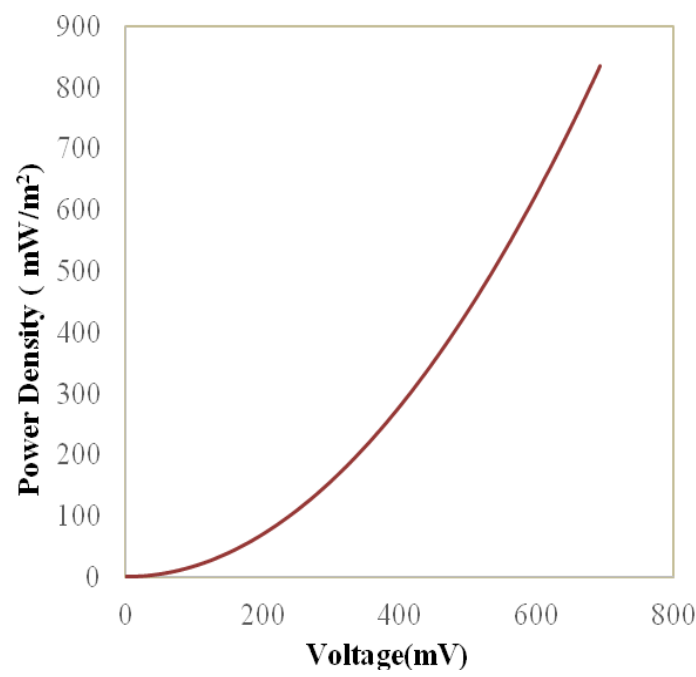

Fig 6. Power density vs Voltage graph I Stainless Steel Cathode and Graphite Anode

\section{B. MFC configuration-2}

The total power generated for $1 \mathrm{~m}^{2}$ area of the Aluminum electrode was $32050.31 \mathrm{~mW}$. The Actual power generated from the electrode area of $0.001225 \mathrm{~m}^{2}$ is $39.26 \mathrm{~mW}$.

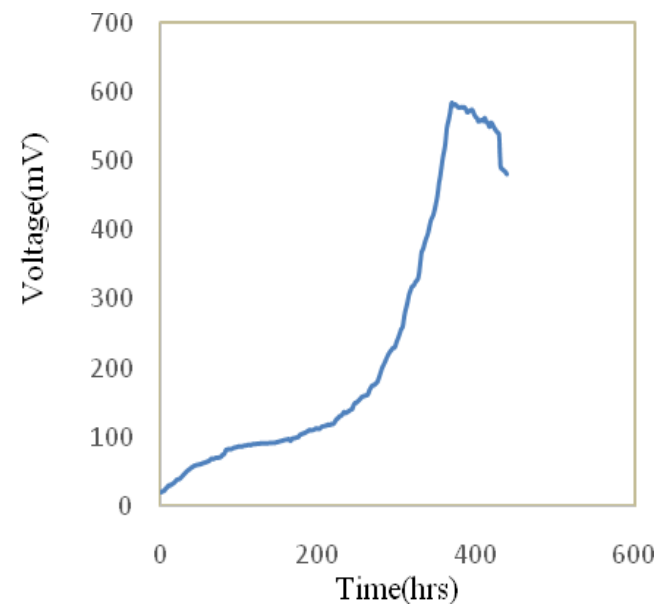

Fig 7. Voltage vs Time graph for Aluminum Cathode and Graphite Anode

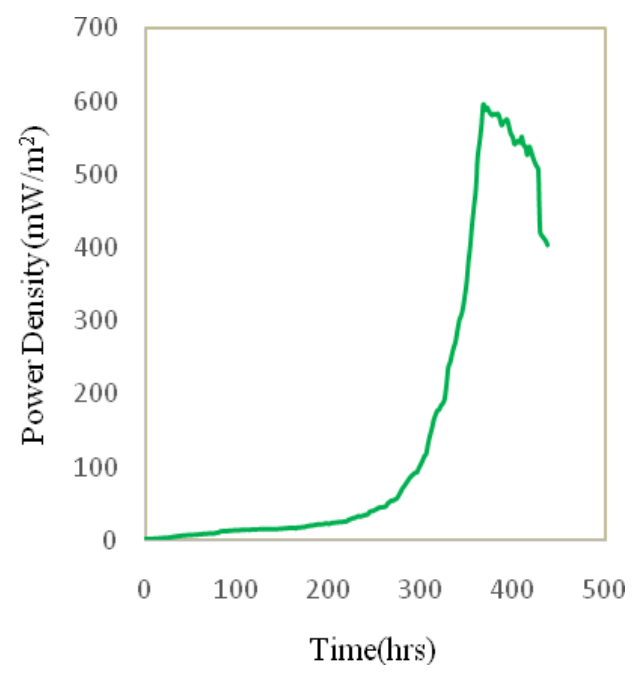

Fig 8. Power density vs Time graph for Aluminum Cathode and Graphite Anode

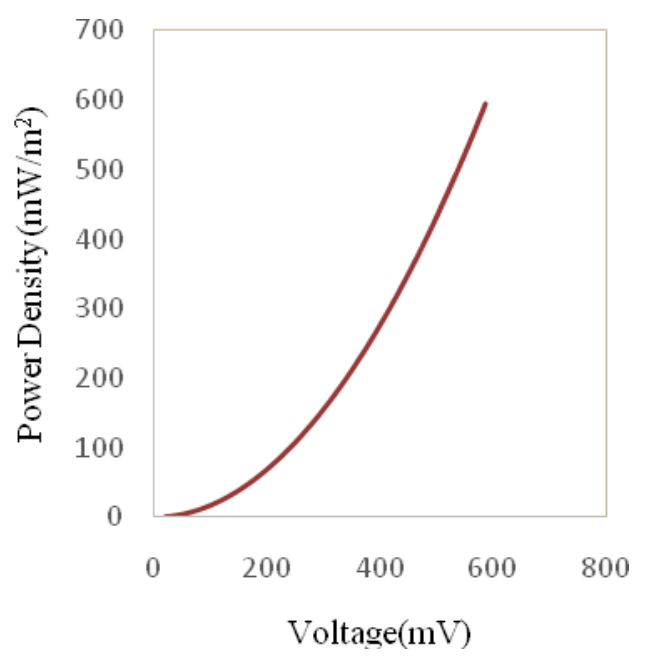

Fig 9. Power density vs Voltage graph for Aluminum Cathode and Graphite Anode

Table- III: Comparison of Effluent Characteristics

\begin{tabular}{l|c|c|c|}
\hline Characteristics & Inlet & After Treatment \\
Published By: & Blue Eyes Intelligence Engineering \\
\& Sciences Publication & Exploring Innovation
\end{tabular}




\begin{tabular}{|l|c|c|c|}
\hline & Effluent & $\begin{array}{c}\text { MFC } \\
\text { SETUP-1 }\end{array}$ & $\begin{array}{c}\text { MFC } \\
\text { SETUP-2 }\end{array}$ \\
\hline COD ppm & 2960 & 678 & 992 \\
\hline TDS ppm & 6000 & 10000 & 9650 \\
\hline TSS ppm & 1200 & 1600 & 1435 \\
\hline pH & 7.2 & 6.8 & 6.8 \\
\hline Color & $\begin{array}{c}\text { Dark } \\
\text { Green }\end{array}$ & $\begin{array}{c}\text { Yellowish } \\
\text { Green }\end{array}$ & $\begin{array}{c}\text { Yellowish } \\
\text { Green }\end{array}$ \\
\hline
\end{tabular}

From the above table it can be seen that there is $77.09 \%$ COD removal while using stainless steel electrode and $66.48 \%$ COD removal while using aluminum electrode. Total solids content has increased duo to bacterial activities in the effluent.

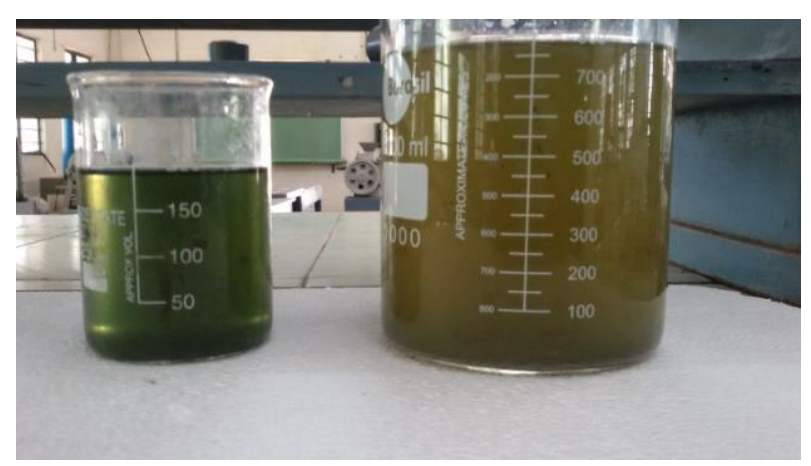

Fig 10. Effluent colour before and after treatment

\section{Comparison of Electrode Material Output}

Due to the varying properties of the electrode the output characteristics of the MFC setups also varied. The output of both the MFC setups was compared and is shown in the figure 11 .

The variation in the output is due to the variation in the electrode potential of the electrodes and the electron accepting capacity of the electrodes.

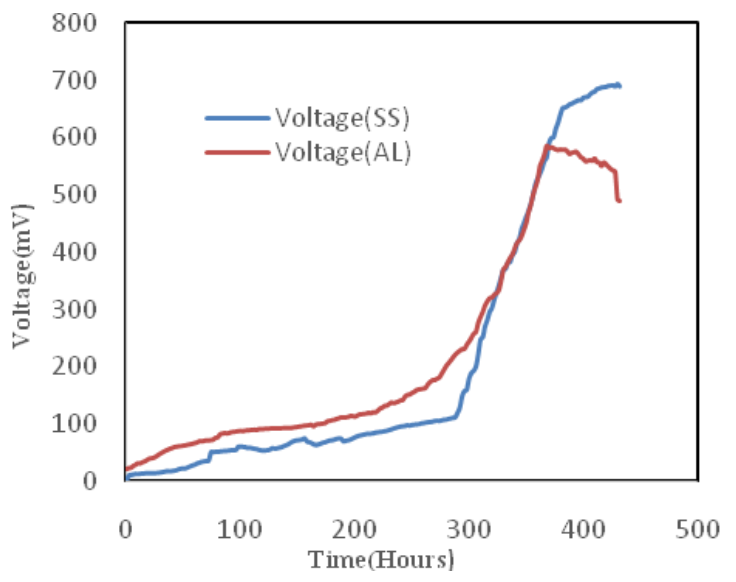

Fig 11. Comparison of output of SS and Aluminum electrode

The raw sludge and the sludge obtained from the treated effluent were collected and were given for SEM analysis. The SEM images are shown below

From the $20 \mu \mathrm{m}$ and $10 \mu \mathrm{m}$ SEM images it is observed that there is growth of bacterial layer on the sludge surface. From these images it is observed that the bacteria have anaerobically reduced the organic matter in the wastewater and have grown by feeding on it.

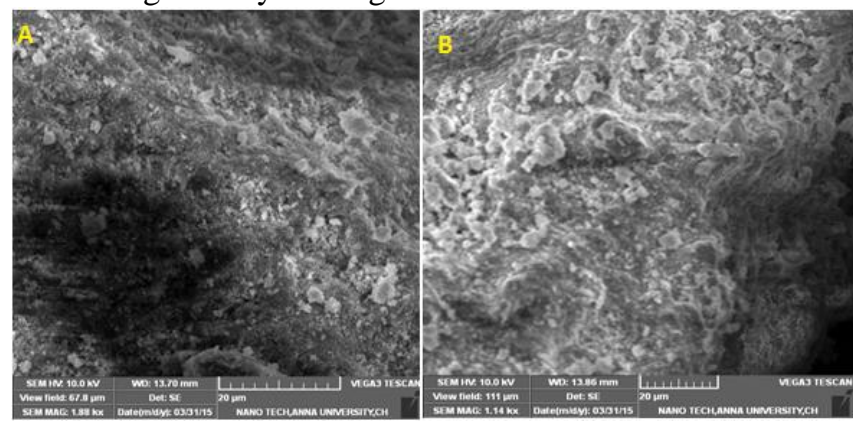

Fig 12. (A) SEM image of textile effluent raw sludge, (B) growth of bacterial layers on the surface of the sludge $(20 \mu \mathrm{m})$

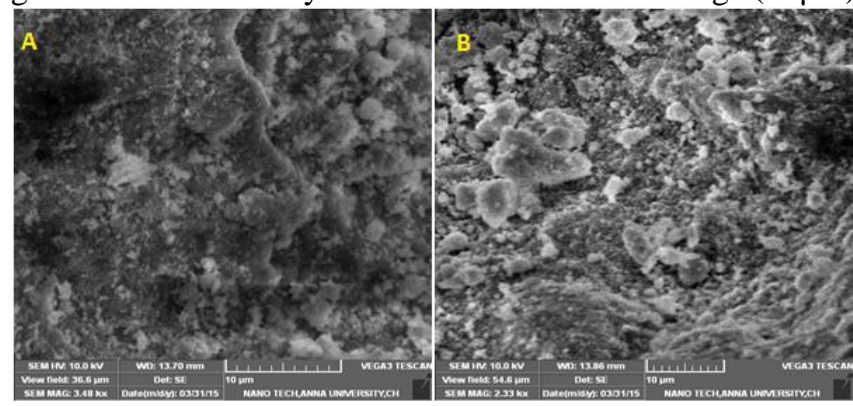

Fig 13. (A) SEM image of textile effluent raw sludge, (B) growth of bacterial layers on the surface of the sludge $(10 \mu \mathrm{m})$

From the Table 3 it is observed that the COD level of the effluent has drastically decreased. About $77.09 \%$ of COD removal is achieved in Graphite-Stainless steel configuration and $66.08 \%$ of COD removal in Graphite-aluminum configuration. From the Obtained results it is observed that the removal of COD in Graphite-stainless steel electrode configuration (77.09) is comparatively higher than that of the Graphite-aluminum electrode configuration (66.08). Similarly the power produced in the Graphite-stainless steel configuration $\left(35.63 \mathrm{~W} / \mathrm{m}^{2}\right)$ is a little bit higher than graphite-aluminum configuration $\left(32.05 \mathrm{~W} / \mathrm{m}^{2}\right)$. From Figure-10 it is observed that there is a reduction in the colour of the effluent. Hence from the experimental data it is observed that the MFC can be efficiently used to treat the textile effluent and to generate clean energy.

\section{CONCLUSION}

Microbial fuel cell has been tested using textile effluent and the output of two different cathode material was compared. The current work has proved successful in implementing the textile effluent as a fuel source for the MFC and further has proven that the MFC help in the reduction of COD level of the effluent. Though the power produced was low there is scope for further improvement by using an electron mediator in the anode chamber and the use of catalyst in the cathode chamber for the easy oxygen facilitation to the protons. From the experimental data the maximum power density obtained from Graphite - stainless steel configuration was $35.63 \mathrm{~W} / \mathrm{m}^{2}$. The maximum voltage reached was $693 \mathrm{mV}$. For the graphite aluminum configuration the maximum power density was obtained as $32.05 \mathrm{~W} / \mathrm{m}^{2}$. The maximum voltage reached was $585 \mathrm{mV}$. There was a considerable decrease in the COD level of the effluent in graphite-stainless steel configuration $77.09 \%$ COD

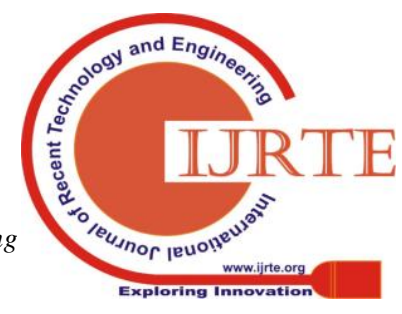


level reduction was seen as for the graphite-aluminum configuration it was $66.48 \%$.Thus from the experimental data it is observed that the graphite-stainless steel electrode configuration is more efficient in COD removal than the graphite-aluminum electrode configuration.

\section{REFERENCES}

1. E. Ashley, Franks and Kelly P.Nevin, "Microbial Fuel Cells A Current Review," Energies, 2010, pp. 899-919.

2. J. Sevrin-Reyssac, "Bio treatment of swine manure by production of aquatic valuable biomasses," Agric. Ecosystem. Environ., 1998, 68, pp. $177-186$.

3. D. Singh, D.Pratap, Y.Baranwal, B.Kumar and R.K.Chaudhary, "Microbial fuel cells: A green technology for power generation," Annals of Biological Research, pp. 128-138, 2010

4. S. Venkata Mohan., R. Saravanan, S.V. Raghavulu, G. Mohanakrishna and P.N. Sarma, "Bioelectricity production from wastewater treatmen in dual chambered microbial fuel cell (MFC) using selectively enriched mixed microflora: Effect of catholyte," Bioresource Technology, Vol 99(3), pp. 596-603.

5. L.B. Wingard, C.H. Shaw and J.F. Castner, "Bio-electrochemical fuel cells," Enzyme Microb.Technol., 1982, Vol. 4(2), pp. 137-142.

6. Derek R. Lovley, Microbial Energizers: Fuel Cells That Keep on Going Microbes that produce electricity by oxidizing organic compounds in Biomass may someday power useful electronic devices. Microbes, 2006, Vol. 1 (11), pp. 323-329.

7. L. Haiping, , L. Guangli, Z. Renduo and J. Song,, "Phenol degradation in microbial fuel cells," Chem. Eng. Journal, 2008, 147, pp. 259-264.

8. K.M. Aswin, and M. Florian, "The internalresistance of a microbial fuel cell and itsdependence on cell design and operating conditions," Electrochimical Acta., 2009, 54, pp. 1664-1670.

9. L. Huang,, R.J. Zeng and I. Angelidaki, "Electricity production from xylose using amediator-less microbial fuel cell," Bioresource Technol., 2008, 99, pp.- 4178-4184.

10. Bruce, E., logan, Microbial fuel cells, Wiley-Interscience, 2007

11. Bennetto, H. P., "Electricity Generation by Micro-organisms," Biotechnology Education, 1990, Vol. 1 (4), pp. 163-168.

12. Jiang Junqiu, Zhao Qingliang, Zhang Jinna, Zhang Guodong and Lee Duu-Jong, "Electricity generation from bio-treatment of sewage sludge with microbial fuel cell," Bioresource Technology, 2009, Vol. 100 (3), pp. 5808-5812.

13. F. D. Sisler, Biochemical Fuel Cells, in Progress in Industrial Microbiology, D. J. D. Hockenhull (Ed), J. \& A. Churchill, London, 9, pp. $1-11,1971$

14. A.P.F Turner, W. J. Aston, I. J. Higgins, G. Davis and H. A. O. Hill, "Applied Aspects of Bioelectrochemistry: Fuel Cells, Sensors, and Bioorganic Synthesis, in Fourth Symposium on Biotechnology in Energy Production and Conservation," C. D. Scott (Ed), Interscience, New York, pp. 401, 1982.

15. G.T.R. Palmore and G. M. Whitesides, "Microbial and Enzymatic Biofuel Cells in Enzymatic Conversion of Biomass for Fuels Production," M. E. Himmel, J. O. Baker and R. P. Overend (Eds), ACS Symposium Series, No. 566, American Chemical Society, Washington, DC, 1994, pp. 271-290.

16. Zhuwei Dua, Haoran $\mathrm{Li}$ and Tingyue Gu, "A state of the art review on microbial fuel cells: A promising technology for wastewater treatment and bioenergy, " Biotechnology Advances, 2007, pp. 464-482.

17. Ishwar Chandra, "Waste to Energy: Microbial Fuel Cell a Novel Approach To Generate Bio-Electricity," International Journal Of Advanced Biotechnology And Bioinformatics, 2012.

18. Booki Min, JungRae Kim, SangEun Oh, John M.Regana, Bruce E. Logan, "Electricity generation from swine wastewater using microbial Fuel cells," Water Research, 2005, pp. 4961-496.

19. M.M. Ghangrekar and V.B. Shinde, "Wastewater Treatment in Microbial Fuel Cell and Electricity Generation: A Sustainable Approach," Paper presented in the $12^{\text {th }}$ international sustainable development research conference, 2006, pp. 6-8.

20. S.Fatemi, A.Ghoreyshi, G.Najafpour and M.Rahimnejad, "Bioelectricity Generation in Mediator - Less Microbial Fuel Cell: Application of Pure and Mixed Cultures," Iranica Journal of Energy \& Environment, 2012, pp. 104-108.

\section{AUTHORS PROFILE}

Dr.C. Marimuthu, is currently working as Associate Professor in the

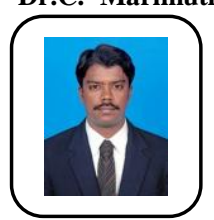
Department of Chemical Engineering in Sethu Institute of Technology, Kariapatti, Virudhunagar, India. His research area is biofuels and Lifecycle assessment. He has published more than 10 research papers in international journal.

S.Vidya is currently working as Assistant professor in the Department of Computer Science and Engineering in

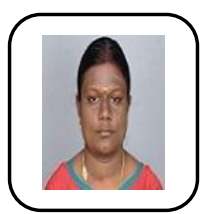
Kalasalingam Institute of Technology, Krishnankoil, Srivilliputhur, India and pursuing Ph.d. in Anna University, Chennai. She is a $27^{\text {th }}$ rank holder in M.E. Her research area is wind speed forecasting using deep learning techniques.

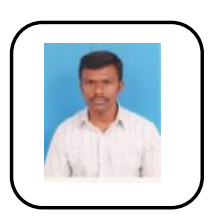

Dr. S.Diwakaran , working as Assistant Professor, Department of Electronics and Communication Engineering, Kalasalingam Academy of Research and Education. His research areas include wireless networks, Network Security, Distributed Networks and Management studies. He had published more than 6 reputed journals. 